\title{
Psychedelic Medicine: Past, Present, and Future
}

Directors: William Prueitt, M.D. (william.prueitt@yale.edu) and Jordan Sloshower, M.D., M.Sc.

Dates: 8 sessions held weekly from October - December 2020

Time: Wednesdays from 5:30-7:00pm

Location: Zoom video conference

Maximum Number: 12

Recommended Years: Open to all healthcare professionals, trainees, and students

\section{Course Description:}

The fields of psychedelic science and medicine are rapidly expanding with increasing numbers of preclinical and clinical investigations being initiated each year. Research studies conducted to date have shown that psychedelics hold promise as therapeutics for a range of mental health conditions and also have the ability to alter brain circuitry, induce positive changes in attitudes and values, facilitate personality changes, and affect political views and mindfulness, among other constructs. Accordingly, increasing numbers of researchers, clinicians, and mental health professional trainees are becoming interested in the field and seeking training and education in this area. This elective seminar serves both as an introduction to core topics in this field and as an opportunity to critically explore the scientific, political, and ethical issues that permeate its past, present, and future.

This elective is primarily a reading seminar focused on participatory group discussions of 2-3 assigned readings per class. Short introductions to the week's topic will generally be provided and materials may also include short videos. The course will begin with a discussion of indigenous uses of psychedelic plants and early Western research with psychedelic substances. We will then explore modern therapeutic applications and proposed mechanisms of action and change. Finally, we will examine issues important to the future of the field, including medicalization, equity and access for diverse populations, and potential models for clinical treatment.

\section{Learning Objectives:}

1. Synthesize scholarship from across the biological, psychological, and social sciences into an interdisciplinary understanding of psychedelic substances and their potential therapeutic applications.

2. Describe the historical context for current psychedelic research, including early research and indigenous uses.

3. Identify neurobiological, psychological, and spiritual mechanisms by which psychedelics may function as therapeutics for mental health disorders.

4. Analyze the complex set of political, commercial, and ethical issues facing the field of psychedelic medicine as it moves towards medicalization. 
$\underline{\text { Weekly Syllabus }}$

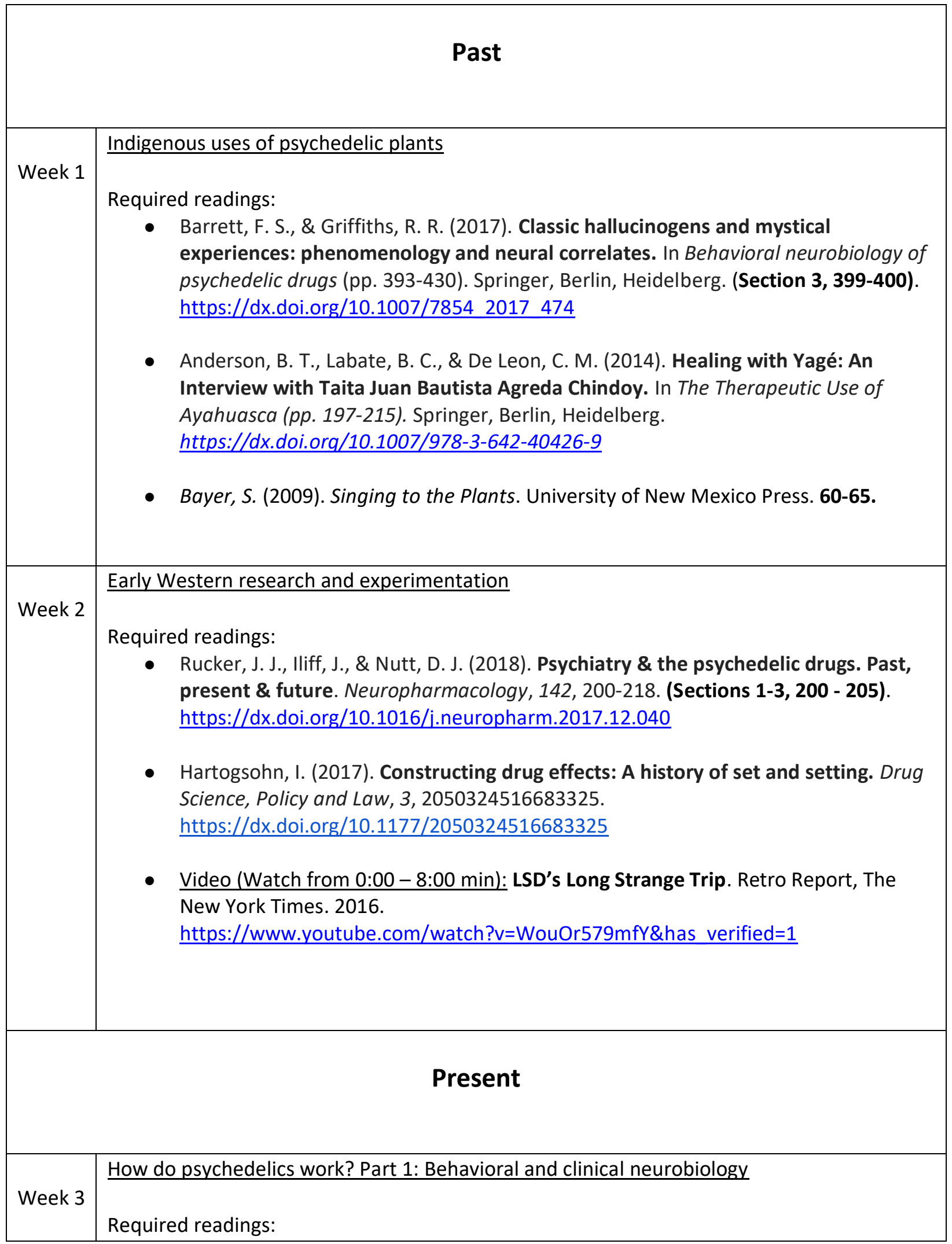




\begin{tabular}{|c|c|}
\hline & $\begin{array}{l}\text { - Carhart-Harris, R. L. (2019). How do psychedelics work?. Current opinion in } \\
\text { psychiatry, 32(1), 16-21. https://dx.doi.org/10.1097/yco.0000000000000467 } \\
\text { - Vollenweider, F. X., \& Preller, K. H. (2020). Psychedelic drugs: neurobiology and } \\
\text { potential for treatment of psychiatric disorders. Nature Reviews Neuroscience, 1- } \\
\text { 14. https://dx.doi.org/10.1038/s41583-020-0367-2 } \\
\text { Additional resources for further study: } \\
\text { - Carhart-Harris, R. L., \& Friston, K. J. (2019). REBUS and the anarchic brain: toward a } \\
\text { unified model of the brain action of psychedelics. Pharmacological reviews, 71(3), } \\
\text { 316-344. https://dx.doi.org/10.1124/pr.118.017160 }\end{array}$ \\
\hline Week 4 & $\begin{array}{l}\text { How do psychedelics work? Part 2: Healing and mystical-type experiences } \\
\text { Required readings: } \\
\text { - Kirmayer, L. J. (2004). The cultural diversity of healing: meaning, metaphor and } \\
\text { mechanism. British medical bulletin, 69(1), 33-48. } \\
\text { https://dx.doi.org/10.1093/bmb/ldh006 } \\
\text { - Barrett, F. S., \& Griffiths, R. R. (2017). Classic hallucinogens and mystical } \\
\text { experiences: phenomenology and neural correlates. In Behavioral neurobiology of } \\
\text { psychedelic drugs (pp. 393-430). Springer, Berlin, Heidelberg. } \\
\text { https://dx.doi.org/10.1007/7854 2017 } 474\end{array}$ \\
\hline Week 5 & 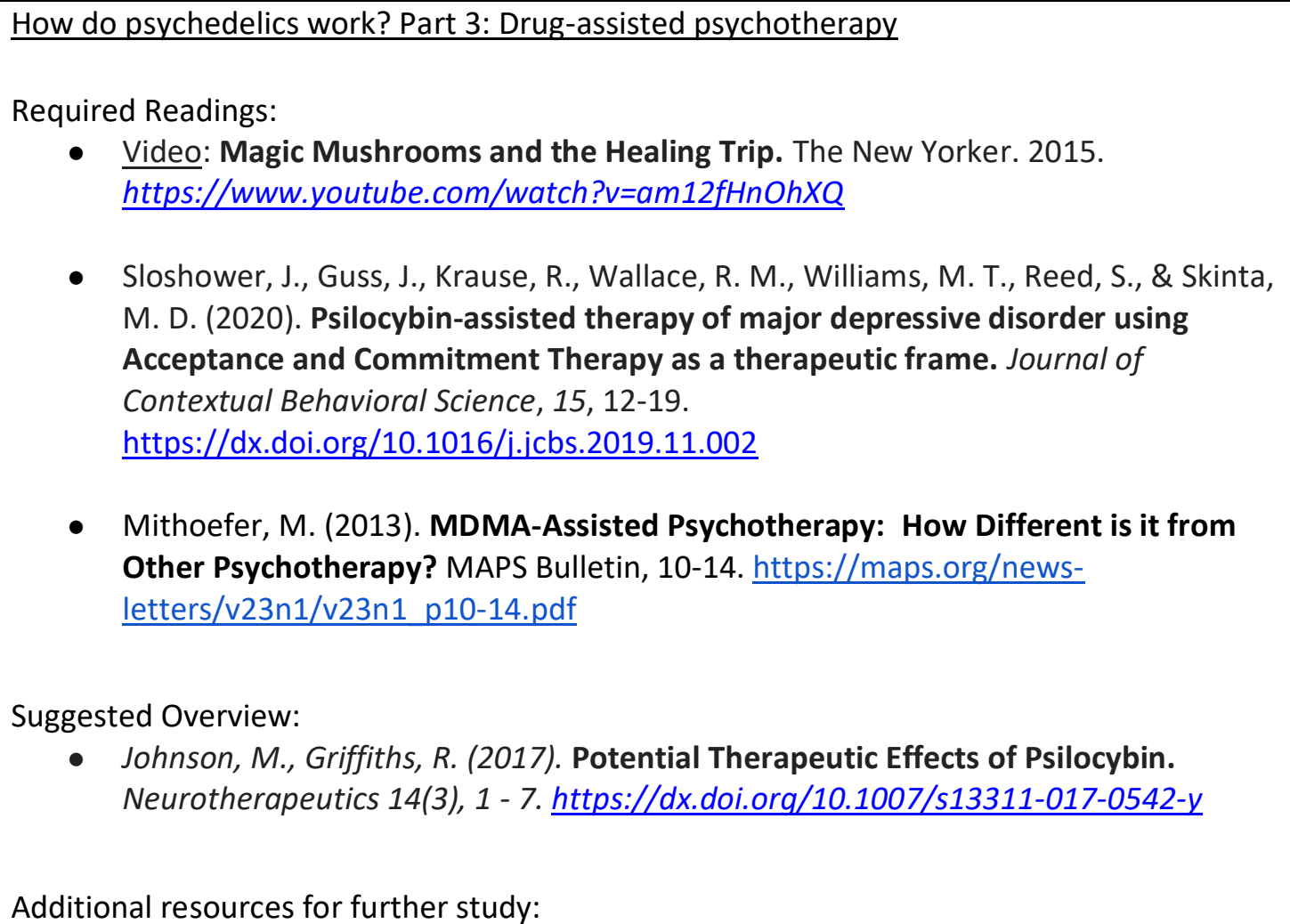 \\
\hline
\end{tabular}




\begin{tabular}{|c|c|}
\hline & $\begin{array}{l}\text { Video (Start at 5:45min): Pollan, Michael. Psychedelics and How to Change Your } \\
\text { Mind. Bioneers. 2018. https://www.youtube.com/watch?v=5DrM90dg5t4 } \\
\text { - Swift, T. C., Belser, A. B., Agin-Liebes, G., Devenot, N., Terrana, S., Friedman, H. L., ... } \\
\text { \& Ross, S. (2017). Cancer at the dinner table: experiences of psilocybin-assisted } \\
\text { psychotherapy for the treatment of cancer-related distress. Journal of Humanistic } \\
\text { Psychology, 57(5), 488-519. https://dx.doi.org/10.1177/0022167817715966 } \\
\text { Bogenschutz, M. P., \& Forcehimes, A. A. (2017). Development of a } \\
\text { psychotherapeutic model for psilocybin-assisted treatment of alcoholism. Journal } \\
\text { of Humanistic Psychology, 57(4), 389-414. } \\
\text { https://dx.doi.org/10.1177/0022167816673493 }\end{array}$ \\
\hline Week 6 & $\begin{array}{l}\text { Frontiers and controversial topics in psychedelic research } \\
\text { Required readings: } \\
\text { - Kaelen, M., Giribaldi, B., Raine, J., Evans, L., Timmerman, C., Rodriguez, N., .. \& } \\
\text { Carhart-Harris, R. (2018). The hidden therapist: evidence for a central role of music } \\
\text { in psychedelic therapy. Psychopharmacology, 235(2), 505-519. } \\
\text { https://dx.doi.org/10.1007/s00213-017-4820-5 } \\
\text { - Lyons, T., Carhart-Harris, R. (2018). Increased nature relatedness and decreased } \\
\text { authoritarian political views after psilocybin for treatment-resistant depression. } \\
\text { Journal of Psychopharmacology 32(7), 811-819. } \\
\text { https://dx.doi.org/10.1177/0269881117748902 } \\
\text { - Hendricks, P., Crawford, M., Cropsey, K., Copes, H., Sweat, N., Walsh, Z., Pavela, G. } \\
\text { (2018). The relationships of classic psychedelic use with criminal behavior in the } \\
\text { United States adult population. Journal of psychopharmacology (Oxford, England) } \\
\text { 32(1), } 37 \text { - 48. https://dx.doi.org/10.1177/0269881117735685 }\end{array}$ \\
\hline & Future \\
\hline Week 7 & $\begin{array}{l}\text { Diversity, equity, and inclusion in psychedelic medicine } \\
\text { Required readings: } \\
\text { - Williams, M., Reed, S., Aggarwal, } R .(2020) \text {. Culturally informed research design } \\
\text { issues in a study for MDMA-assisted psychotherapy for posttraumatic stress } \\
\text { disorder. Journal of Psychedelic Studies } 4(1), 40-50 . \\
\text { https://dx.doi.org/10.1556/2054.2019.016 }\end{array}$ \\
\hline
\end{tabular}




\begin{tabular}{|c|c|}
\hline & $\begin{array}{l}\text { - George, J., Michaels, T., Sevelius, J., Williams, M. (2020). The psychedelic } \\
\text { renaissance and the limitations of a White-dominant medical framework: A call } \\
\text { for indigenous and ethnic minority inclusion. Journal of Psychedelic Studies 4(1), 4- } \\
\text { 15. https://dx.doi.org/10.1556/2054.2019.015 } \\
\text { Additional resources for further study: } \\
\text { - Michaels, T., Purdon, J., Collins, A., Williams, M. (2018). Inclusion of people of color } \\
\text { in psychedelic-assisted psychotherapy: a review of the literature BMC Psychiatry } \\
\text { 18(1), } 1 \text { - 14. https://dx.doi.org/10.1186/s12888-018-1824-6 }\end{array}$ \\
\hline Week 8 & $\begin{array}{l}\text { Models of psychedelic science and treatment } \\
\text { Required readings:: } \\
\text { - Sloshower, J. (2018). Integrating Psychedelic Medicines and Psychiatry: Theory } \\
\text { and Methods of a Model Clinic. In Plant Medicines, Healing and Psychedelic Science } \\
\text { (pp. 113-132). Springer, Cham. https://dx.doi.org/10.1007/978-3-319-76720-8 } \\
\text { - Fotiou, E. (2019). The role of Indigenous knowledges in psychedelic science. } \\
\text { Journal of Psychedelic Studies 4(18), } 1 \text { - 8. } \\
\text { https://dx.doi.org/10.1556/2054.2019.031 } \\
\text { - McGaughey, Dave (2019). We Will Call It PALA. Aurynproject.org/pala }\end{array}$ \\
\hline
\end{tabular}


Other Recommended Readings:

Topic Overview:

- Nichols, D. (2016). Psychedelics. Pharmacological Reviews 68(2), 264 - 355. https://dx.doi.org/10.1124/pr.115.011478

- Garcia-Romeu, A., Kersgaard, B., Addy, P. (2016). Clinical applications of hallucinogens: A review. Experimental and Clinical Psychopharmacology 24(4), 229 - 268. https://dx.doi.org/10.1037/pha0000084

Safety and Regulatory Considerations:

- Johnson, M., Richards, W., Griffiths, R. (2008). Human hallucinogen research: guidelines for safety. Journal of Psychopharmacology 22(6), 603 - 620. https://dx.doi.org/10.1177/0269881108093587

- Johnson, M., Griffiths, R., Hendricks, P., Henningfield, J. (2018). The abuse potential of medical psilocybin according to the 8 factors of the Controlled Substances Act. Neuropharmacology https://dx.doi.org/10.1016/j.neuropharm.2018.05.012

Therapist Competencies:

- Phelps, J. (2017). Developing guidelines and competencies for the training of psychedelic therapists. Journal of Humanistic Psychology 57(5), 450 - 487.

https://dx.doi.org/10.1177/0022167817711304 